Review

\title{
Wastewater Recycling in Greece: The Case of Thessaloniki
}

\section{Andreas Ilias ${ }^{1, *}$, Athanasios Panoras ${ }^{1}$ and Andreas Angelakis ${ }^{2}$}

1 Land Reclamation Institute of Thessaloniki, Hellenic Agricultural Organization DEMETER-N.AG.RE.F., 57400 Sindos Thessaloniki, Greece; E-Mail: panoras.LRI@nagref.gr

2 Institute of Iraklion, Hellenic Agricultural Organization DEMETER-N.AG.RE.F., 71307 Iraklion and Hellenic Water Supply and Sewerage Services Association, 41222 Larissa, Greece; E-Mail: info@a-angelakis.gr

* Author to whom correspondence should be addressed; E-Mail: anilias.LRI@nagref.gr; Tel.: +30-2-310-798-790; Fax: +30-2-310-796-352.

Received: 23 January 2014; in revised form: 4 May 2014 / Accepted: 4 May 2014 /

Published: 13 May 2014

\begin{abstract}
In Greece, and particularly in many southeastern and island areas, there is severe pressure on water resources, further exacerbated by the high demand of water for tourism and irrigation in summertime. The integration of treated wastewater into water resources management is of paramount importance to meet future demands. Despite this need, only a few projects of effluent reuse have been implemented, most of them being pilot projects of crop or landscape irrigation. The most important projects which are currently in practice are those of Thessaloniki, Chalkida, Malia, Livadia, Amfisa, Kalikratia, and Chersonissos. In Thessaloniki, at the most important wastewater reuse site, the secondary effluent of the city's Waste Water Treatment Plant (WWTP) $\left(165,000 \mathrm{~m}^{3} /\right.$ day) is used for agricultural irrigation after mixing with freshwater at a 1:5 ratio. The main crops irrigated are rice, corn, alfalfa and cotton. A few other projects are under planning, such as that at Iraklion, Agios Nikolaos and several island regions. Finally, it should be mentioned that there are several cases of indirect reuse, especially in central Greece. However, the reuse potential in Greece is limited, since effluent from Athens's WWTP, serving approximately half of the country's population, is not economically feasible due to the location of the plant.
\end{abstract}

Keywords: water recycling; wastewater reuse; wastewater in agriculture, water use in agriculture; agricultural water quality criteria; water reuse in Greece 


\section{Introduction}

Treated wastewater has been increasingly used around the world for irrigation, environmental applications, industrial use, groundwater recharge, urban use, indirect potable use and in some rare cases, direct potable use [1,2]. The principal causes preventing the expansion of effluent reuse worldwide are public health and environmental concerns [2]. To reduce the potential risks to acceptable levels, many countries have set regulations or guidelines governing effluent reuse $[3,4]$.

The climate of Greece is sub-humid Mediterranean with humid and relatively cold winters and dry and warm summers, with an average rainfall of $874 \mathrm{~mm} /$ year $\left(115,937 \mathrm{Mm}^{3} /\right.$ year). Greece is characterized by high temporal and spatial precipitation imbalance, with low precipitation and increased water demands for irrigation and tourism during the summer. Annual rainfall ranges from 300 to $500 \mathrm{~mm}$ in southeastern Greece and from 800 to $1200 \mathrm{~mm}$ in the northwestern plains of the mainland, while in some mountainous areas it may be above $2000 \mathrm{~mm}$. It is worth mentioning that during dry years, and at the most hot and arid areas of the country, the irrigation period may be as long as 6 to 7 months. Effluent from WWTPs is an alternative water resource that should be considered in order to catch up with the demand [5,6].

A high potential of reusing treated wastewater for crop and landscape irrigation has been reported in Greece by several researchers ([7-10] and others). In 2009, it was estimated that more than $75 \%$ of the Greek population was connected to WWTPs with a total capacity of over $1.50 \mathrm{~mm}^{3} /$ day [10]. An analysis of data concerning the water balance of the areas served by WWTPs has demonstrated that more than $83 \%$ of the treated effluents are produced in regions with a negative water balance [9].

In this paper, the wastewater treatment and reuse status in Greece, in terms of treatment technology, effluent quality, legislation, and future perspectives is presented. Emphasis is given to the major water recycling project in Greece, which is the reuse of the Thessaloniki WWTP effluent for crop irrigation.

\section{Wastewater Treatment Technologies and Status}

Greece, with a population of approximately 11 million inhabitants, has to comply with the EU Urban Wastewater Treatment Directive (271/91) treatment [11]. According to this Directive, Greece as a member of EU, was bound to connect all urban agglomerations with more than $2000 \mathrm{PE}$ (population equivalents) to WWTPs by the end of 2005. In 2005, it was reported by Tsagarakis that about 350 WWTPs served over $75 \%$ of the country's permanent population [9]. In 2010, the Greek Ministry of Environment, Energy and Climate Change reported that $100 \%, 93 \%, 74 \%$ and $32 \%$ of the population living in agglomerations of over 150,000 EP, 15,000-150,000 EP, 10,000-15,000 EP and 2000-10,000 EP, respectively, were covered by complying to the EU regulations for WWTPs ([12]. Furthermore, it is noted that $10 \%$ of the population live in villages of less than $500 \mathrm{PE}$, for which onsite sanitation technologies should be applied.

Thus far, a number of different technologies for municipal wastewater treatment have been adopted in Greece. Out of them, 88\% are activated sludge systems, 10\% are natural systems and $2 \%$ are attached growth systems. Activated sludge systems are comprised of $85 \%$ extended aeration systems, $10 \%$ conventional systems and 5\% sequencing batch reactors. It is obvious that extended aeration is the dominant system, as it provides significant advantages for the 
Mediterranean climatic conditions. Out of the activated sludge systems, $44 \%$ remove nitrogen and $15 \%$ remove phosphorous [13].

In the early years of wastewater treatment implementation, Greece was lacking the necessary knowledge and its own regulations, and therefore the effluent was either tossed away or reused following other countries' regulations. Until recently, most of the country's WWTPs outflows were driven to sea, or to permanent or ephemeral water bodies, such as lakes, rivers or torrents. Occasionally treated wastewater was applied at agricultural or forest land. However, during the last years, water recycling has increasingly been adopted instead of disposal, mainly for crop, forestry or landscape irrigation [9].

\section{Water Effluent Quality}

An early evaluation of the performance of WWTPs, taking into account physicochemical and biological parameters, was performed by Tsagarakis et al. [13]. According to that study, $42 \%$ of the operating WWTPs performed well, $41 \%$ moderately and 17\% poorly. These findings also revealed a positive correlation between the size of WWTP and effluent quality. Furthermore, Mamais et al. [14] investigating the quality of effluent from fifteen large WWTPs, representing the $60 \%$ of effluent volume in Greece, found that most of these WWTPs appeared to comply with EC Directive 91/271 for the produced effluent. Most of the reported WWTPs performed well in terms of $\mathrm{BOD}_{5}$ and TSS removal. However, a few higher $\mathrm{BOD}_{5}$ values have been reported for some WWTPs due to insufficient aeration, or foaming incidents, or to overloading, especially during the summer [10,15]. Increased levels of salts in the effluent of a number of WWTPs suggest that appropriate management practices should be implemented when it is to be used for agricultural reuse, to ensure land sustainability and productivity. Salinity problems are more frequent in WWTPs located at coastal areas, likely due to seawater intrusion [8], or intrusion from shallow saline aquifers into the municipal sewerage systems. In terms of trace elements, limited data are available, but it appears that they do not pose a risk for the environment or public health [2,16]. Finally, the microbiological parameters fecal coliforms (FC) and total coliforms (TC) range from 0 to 500 and 3,0 to $1500 \mathrm{MPN} / 100 \mathrm{~mL}$ respectively, in the major WWTPs of Greece [10].

\section{History of Water Recycling and Reuse in Greece}

Land application of wastewater is an old and common practice, which has gone through different development stages with time, knowledge, treatment technology, and regulation evolution [17]. Greece, as is the case with other European regions, has a long history on wastewater reuse, as it has been practiced since the Ancient Greek and Roman civilizations [18]. Wastewater was used for irrigation in Mediterranean cities in the 14th and 15th centuries in, for example, the Milanese Marcites and the Valencia huerta, in addition to central and northern European countries like Great Britain, Germany, France, and Poland [19]. Land application of wastewater was practiced in modern Greece in the late 1970s, just before the establishment of the first WWTP. 


\section{Effluent Recycling and Reuse in Greece: Major Projects}

Although many regions of Greece, especially its southeastern regions, are under water stress, effluent reuse is not practiced widely. Tsagarakis et al. [20] estimated that by reusing effluent of existing WWTPs, in order to increase water availability for crop irrigation and ensure environmental protection, $3.2 \%$ of the total water currently used for irrigation would be saved. This percentage has actually been exceeded to $4.5 \%$ [10]. However, the lack of a recycling context and the complex approval processes have inhibited the development of well-organized water recycling projects. Over the last few years, however, the concern for effluent reuse has arisen and many recycling projects are being implemented or planned in Greece, mainly for crop or landscape irrigation.

In Thessaloniki, the secondary effluent of the WWTP $\left(165,000 \mathrm{~m}^{3} /\right.$ day), is used for agricultural irrigation of the Halastra-Kalohori area, after mixing with freshwater from the Axios River at a 1:5 ratio. Approximately 2500 ha of spring crops are irrigated in the Halastra-Kalohori area, with the freshwater-effluent mixture. A recycling scheme has been in operation at the surrounding area of Chalkida since 1998 for landscape irrigation [21]. In the WWTP that is located on the island of Ioannina, the effluent receives tertiary treatment which includes coagulation, filtration, UV disinfection and chlorination. The infrastructure includes four underwater pipes of a total length of $2500 \mathrm{~m}$ for effluent transportation, an effluent storage tank of $200 \mathrm{~m}^{3}$, a distribution network, and a supervision control and data acquisition system for the treatment and irrigation procedures. In this project, approximately $4000 \mathrm{~m}^{3} /$ day are recycled for tree and shrub irrigation. A number of small wastewater reuse projects are in operation around the country, such as those at Chersonisos, Crete $\left(4500 \mathrm{~m}^{3} /\right.$ day $)$ mainly for agricultural irrigation, and secondarily for fire protection and landscape irrigation, at Malia $\left(2500 \mathrm{~m}^{3} /\right.$ day), at Levadia $\left(3500 \mathrm{~m}^{3} /\right.$ day $)$, at the island of $\operatorname{Kos}\left(3500 \mathrm{~m}^{3} /\right.$ day $)$, at Amfissa $\left(400 \mathrm{~m}^{3} /\right.$ day), and at Nea Kalikratia $\left(800 \mathrm{~m}^{3} /\right.$ day $)$. A more recent water reuse project has been in operation in the city of Iraklion (Crete) since 2012. The effluent of a tertiary treatment plant $\left(9500 \mathrm{~m}^{3} /\right.$ day $)$, which includes coagulation, filtration, and UV disinfection, is used for grape and olive tree irrigation, in the southwestern area of the city. Furthermore a membrane bioreactor (MBR) treatment and reuse plant is under construction at the same area.

A few other projects are under planning, such as the one at Agios Nikolaos in eastern Crete, at Lamia in central Greece, and on several Aegean islands. Finally, it should be mentioned that there are several cases of indirect reuse, especially in central Greece, which occur after the disposal of the treated effluents in rivers and the downstream uptake of the mixed water for irrigation (Larissa, Trikala, Karditsa, Lamia, and Tripolis). The reuse potential in Greece, however, is restricted since effluent recycling from Athens's WWTP, which serves approximately $35 \%$ of the country's population, is most likely not economically feasible, due to the location of the treatment plant (the small island of Psitalia). Assessment of the possibility to transport $20,000 \mathrm{~m}^{3} /$ day of treated effluent from the island back to the city areas for landscape irrigation and industrial use at an estimated cost of $0.40 € / \mathrm{m}^{3}$, was shown to be not cost effective, at least for the time being [22].

In Table 1, the major projects of treated wastewater reuse in Greece are presented, along with the capacity of the WWTPs, the irrigated areas, and the main crops irrigated with recycled water. 
Table 1. Major wastewater reuse sites (adapted from [10,21,23]).

\begin{tabular}{|c|c|c|c|c|}
\hline Project & Region & $\begin{array}{c}\text { Capacity } \\
\left(\mathrm{m}^{3} / \text { day }\right)^{a}\end{array}$ & $\begin{array}{l}\text { Irrigated } \\
\text { area (ha) }\end{array}$ & Crops \\
\hline \multicolumn{5}{|c|}{ Irrigation of agricultural land } \\
\hline Thessaloniki (Sindos) & Central Macedonia & 165,000 & 2500 & Corn, sugar beet, rice, etc. \\
\hline Iraklion & Crete & 9500 & 570 & Grapes and Olive trees \\
\hline Levadia & Central Greece & 3500 & & Cotton, corn \\
\hline Amfissa & Central Greece & 400 & & Olive trees \\
\hline Nea Kalikratia & Central Macedonia & 800 & 150 & Olive trees \\
\hline Chersonissos & Crete & 4500 & 270 & Olive trees \\
\hline Malia & Crete & 2500 & 150 & \\
\hline Archanes & Crete & 550 & 33 & Grapes and olive trees \\
\hline Kos & North Aegean & 3500 & 210 & Olive trees, citrus, etc. \\
\hline Others & & 10,000 & & Various \\
\hline \multicolumn{5}{|c|}{ Irrigation of other land (parks, forest, etc.) } \\
\hline Chalkida & Central Greece & 4000 & 50 & \\
\hline Chersonisssos & Crete & 500 & 8 & \\
\hline Agios Costantinos & North Aegean & 200 & 10 & \\
\hline Kentarchos & North Aegean & 100 & 5 & \\
\hline Kos & North Aegean & 500 & 10 & \\
\hline Karistos & North Aegean & 1450 & 30 & \\
\hline Ierissos & South Aegean & 1500 & 25 & \\
\hline Others & & 2000 & & \\
\hline \multicolumn{5}{|l|}{ Indirect reuse } \\
\hline Larissa & Thessaly & 25,000 & & \multirow{6}{*}{$\begin{array}{l}\text { Cotton, corn, etc } \\
\text { Cotton, corn, etc. } \\
\text { Cotton, olive trees, corn, } \\
\text { etc. }\end{array}$} \\
\hline Karditsa & Thessaly & 15,000 & & \\
\hline Lamia & Central Greece & 15,000 & & \\
\hline Tripoli & Peloponissos & 18,000 & & \\
\hline Others & & 35,000 & & \\
\hline Total & & 318,500 & & \\
\hline
\end{tabular}

${ }^{a}$ The effluent is used only during the dry period of the year, ranging from 3 to 6 months/year depending on climate, agronomical and other local conditions.

\section{Thessaloniki Water Reuse Project}

The Thessaloniki plain is one of the biggest agricultural areas of Greece (100,000 ha), located in the country's northern part. Extended open canal irrigation networks have been constructed to transport water from the Axios and Aliakmon Rivers to the fields. The main irrigated crops are rice, corn, cotton, sugar beet, alfalfa and orchards. During dry years, at the peak of the irrigation period (July-August) the flow of the two rivers that supply the network, especially the one of the Axios, is getting too low and additional water resources are needed in order to meet the demand.

A WWTP effluent reuse project has been built upon the findings of long (more than 10 years) experimental work carried out by the Land Reclamation Institute of the National Agricultural Research Foundation (LRI-NAGREF) in the area of the Thessaloniki WWTP [24]. The location of the WWTP and the recycling scheme of Thessaloniki area are shown in Figure 1. 
Figure 1. The WWTP and the recycling scheme of Thessaloniki [23].

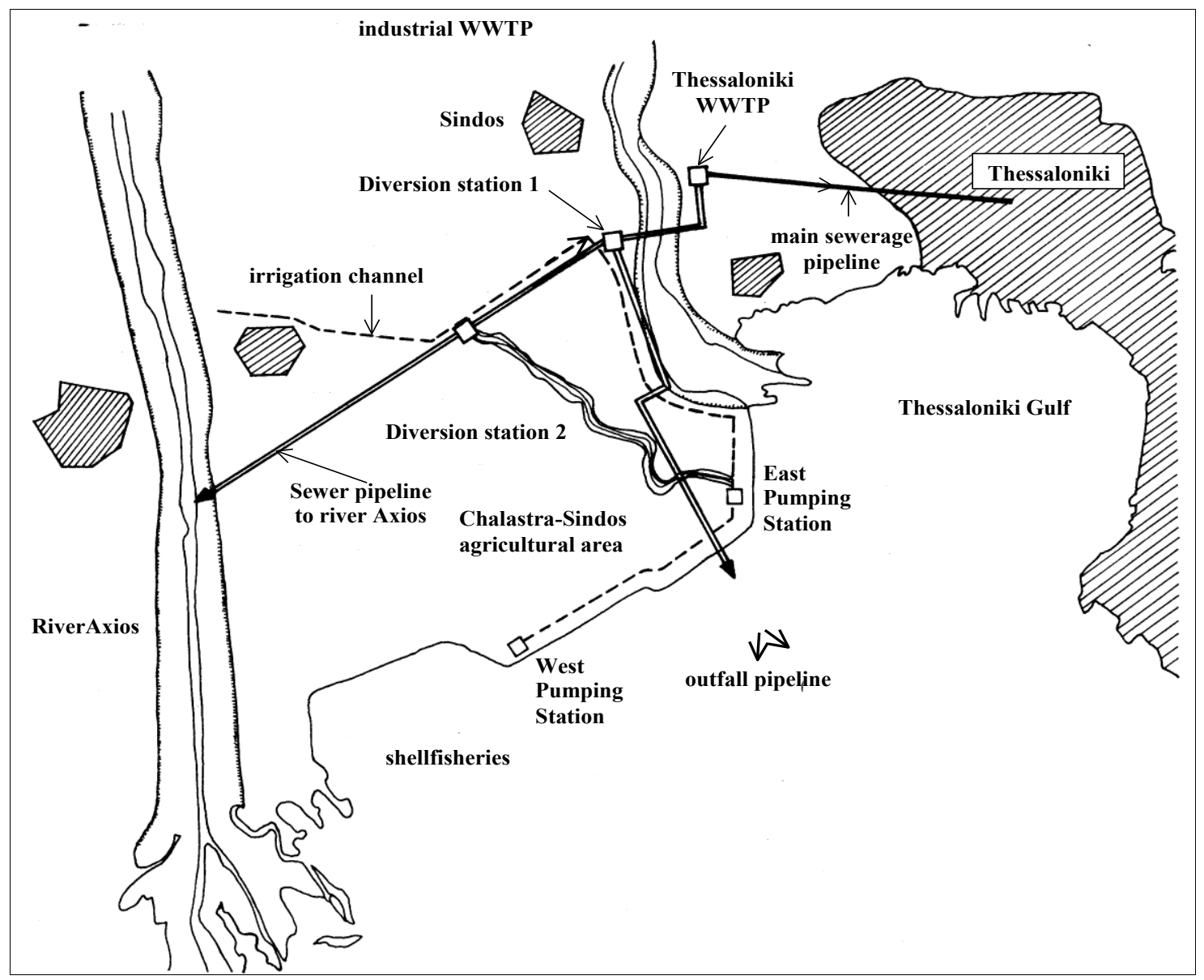

\section{Experimental Work}

In 1995, the Land Reclamation Institute (LRI-NAGREF) began to study and experiment on the utilization of Thessaloniki's WWTP effluent for crop irrigation. The appropriate practices to irrigate sugar beet and cotton (Figure 2), corn and rice (Figure 3), which are the main crops of the neighboring Halastra-Kalohori area, were investigated. During the experimentation, two water qualities, treated wastewater and freshwater (control), were tested in relation to the effects on crop production, soil properties, irrigation equipment and health risk. This important agricultural area with an open-canal collective irrigation network is located nearby Thessaloniki's WWTP (Figure 1), and the farmers often expressed their willingness to use the treated effluent on their fields.

Extended field experiments and research concerning the reuse of the treated effluent for crop irrigation (conducted by LRI-NAGREF) have resulted in the following conclusions.

Irrigation water evaluation. The evaluation of the suitability of the WWTP effluent for irrigation, taking into account its composition and the established agronomical standards, showed that if the recommended practices are followed, it could be safely used without posing high risk to the soil, crop, irrigation systems and human health. However, only rational use of the effluent and systematic surveillance of the system could ensure sustainability and long-term safety.

Soil. As mentioned previously, effluents from near-coast cities and WWTPs often have a high salt content. The use of such effluent increases the soil EC regardless of the irrigation method and, to be on the safe side, the level of the soil salinity and ESP values related to permeability issues have to be 
regularly monitored. Furthermore, taking into account the property of the soil to accumulate substances, long-term soil monitoring should be undertaken.

Figure 2. Experimental fields irrigated with treated wastewater at Sindos, Thessaloniki: (a) sugar beet and (b) cotton.

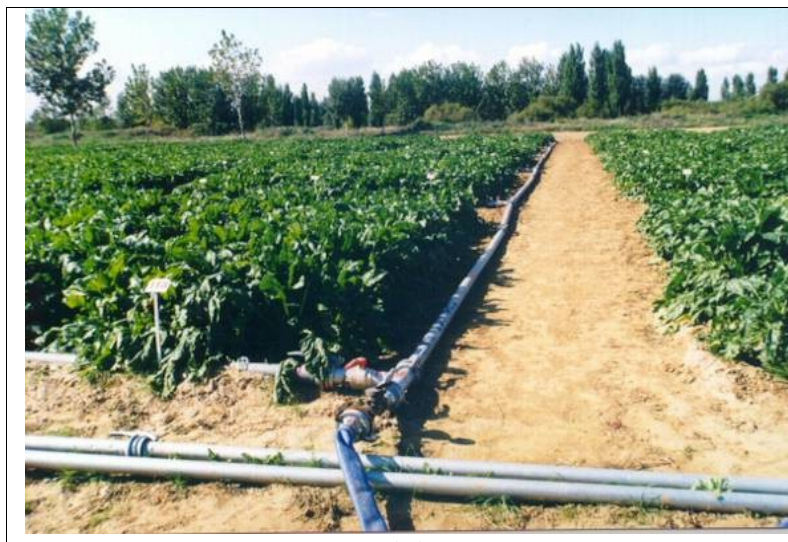

(a)

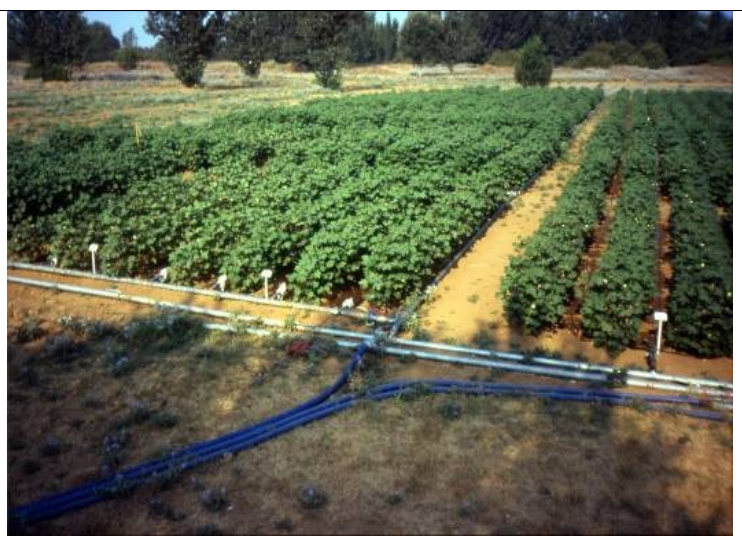

(b)

Figure 3. Experimental fields irrigated with treated wastewater at Sindos, Thessaloniki: (a) corn and (b) rice.

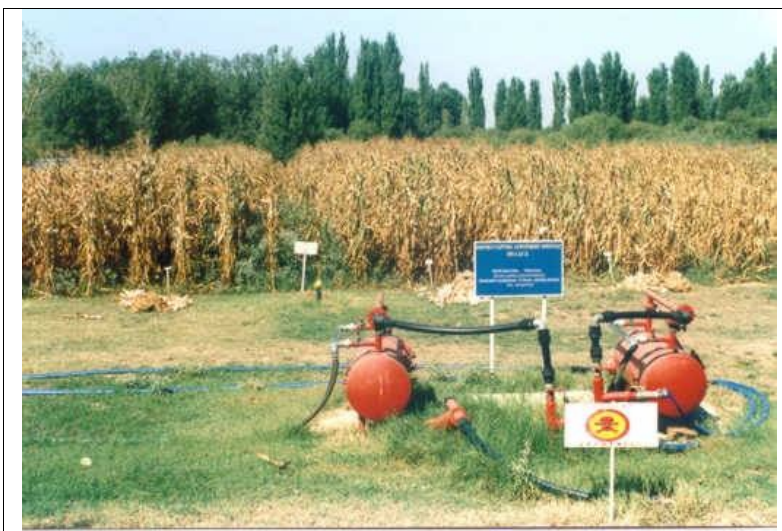

(a)

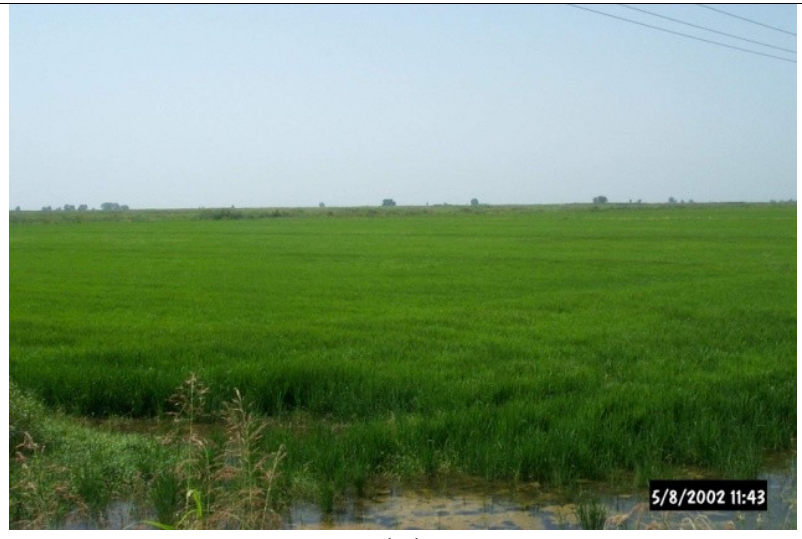

(b)

Trace elements. The trace elements concentration in the soil and plant tissues was quite low compared to the international criteria. This was due to the low concentration of trace elements in the effluent, ensuring a safe long-term use for crop irrigation [16].

Microorganisms. There is no significant health risk from the use of this effluent, because pathogenic microorganisms in the chlorinated effluent were well within the limits, according to various health criteria. Both the level furrows with blocked ends and the drip irrigation system satisfactorily protect the farmers from having contact with the water. Nevertheless, every regulation related to health protection should be strictly followed, as using treated wastewater always involves a potential health risk.

Drip irrigation/Clogging problems. All the emitter tests for the drip irrigation system have shown no emitter clogging even at the far-end of the laterals, after three years of continuous use of the effluent [25]. Furthermore, the test for deposits within the emitters have proved that the cylinder of the labyrinth and the inlet were clean. Only negligible amounts of deposits have been detected on the teeth of the labyrinth. However, there is still need for longer-term experiments. 
Crop yields: Effects of the use of treated wastewater on crop yield were as follows:

(a) Sugar beet. No statistically significant differences either between the two water qualities (effluent and control water) or between the two irrigation methods (furrows and drip irrigation) have been detected, with relation to sugar content and white sugar yield [26].

(b) Cotton. Statistically significant differences in seed cotton yield and lint have been observed between the treated effluent and the control water. The wastewater has resulted in higher yield than the freshwater. There have been no significant differences in cotton quality characteristics between the two water quality treatments. Furthermore, no significant differences in seed cotton yield have been observed between furrow and drip irrigation, unlike the significant differences in lint, fiber length, micronaire and mean maturation date [27].

(c) Corn. The statistical analysis has shown that no significant differences in relation to corn yield have been observed between the two water qualities. On the other hand, there have been significant differences in terms of crop height between the two water qualities, in favor of the corn irrigated with the WWTP effluent. Significant differences in corn yield and crop height have been observed between furrow and drip irrigation. Furrow irrigation has produced 10\% more corn yield than drip irrigation. The statistical analysis of the corn yield and crop height in relation to water quality or irrigation method has shown that the higher the plants, the less seed that is produced. Although the corn breeders have reported a positive correlation between plant height and yield, there are experimental results where no or negative correlation has been observed [28].

(d) Rice. The reuse of the wastewater for rice irrigation has not affected the yield and the quality characteristics in relation to irrigation with freshwater [29].

Conclusions. The evaluation of the results of crop yield and soil data in relation to the water quality and the irrigation method shows that the municipal wastewater of Thessaloniki city treated by activated sludge and chlorination can reinforce the water resources of the Thessaloniki plain. The treated effluent is discharged to the neighboring Halastra-Kalohori irrigation network, and reused after mixing with river water from the Axios. The mixing of the two waters is essential because of the effluent's increased salinity due to seawater intrusion into the sewerage system. Reuse of the treated effluent of the WWTP of Thessaloniki for crop irrigation will save freshwater for other uses and, furthermore, will protect the Gulf of Thessaloniki from pollution [24].

\section{Project Implementation}

The aforementioned findings helped to implement a wastewater reuse scheme to the Halastra-Kalohori irrigation network since 2007 (Figure 4). Part of a wastewater effluent of $165,000 \mathrm{~m}^{3}$ /day from the Thessaloniki WWTP mixed with river water from the Axios is reused to irrigate approximately 2500 ha of rice, corn, alfalfa, sugar beet and cotton. The distribution of the major crops in the irrigated area is shown in Table 2. Water requirements varied from 60 to $111 \mathrm{~m}^{3} / \mathrm{ha} /$ day, for cotton and rice, respectively. The minimum and the maximum water requirements were determined upon the irrigation method and the water application efficiency. In the traditional surface water irrigation methods, the efficiency is less than $70 \%$ [24]. 
Figure 4. Irrigation canal and mixing point of Thessaloniki's WWTP effluent with the river water from the Axios.

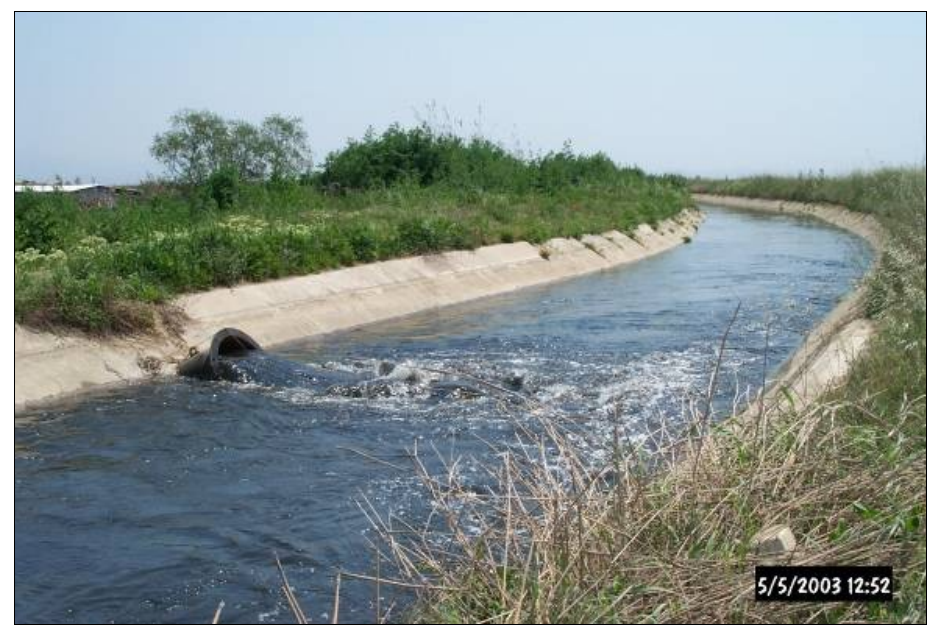

Table 2. Distribution of major crops in the irrigated area of the water reuse project [30].

\begin{tabular}{cccc}
\hline Crops & Area (ha) & Percentage $(\%)$ & $\begin{array}{c}\text { Water requirements } \\
\left(\mathbf{m a x} \text { and } \mathbf{m i n} \text { in } \mathbf{~ m}^{\mathbf{3}} / \mathbf{h a} / \mathbf{d a y}\right)\end{array}$ \\
\hline Cotton & 104 & 4.26 & $54-66$ \\
Corn & 559 & 22.8 & $62-76$ \\
Alfalfa & 111 & 4.5 & $70-86$ \\
Rice & 1677 & 68.5 & $100-222$ \\
\hline
\end{tabular}

In this implementation, the effluent is mixed with freshwater from the Axios River at a maximum ratio of 1:5 (Figure 4). The exact percentage of wastewater in the mixture depends on the quality of the effluent and especially its salinity, and is decreased if higher than usual salinity values are measured [24]. The Land Reclamation Institute is in charge of the surveillance of the system, checking the quality characteristics of the effluent delivered to the irrigation network and the possible effects of its use. During the early years of the project, the mixed effluent (WWTP effluent mixed with the Axios's river water) should follow the quality criteria: $\mathrm{pH} 6.5-8.5, \mathrm{EC}<3.0 \mathrm{dS} / \mathrm{m}, \mathrm{BOD}_{5}<20 \mathrm{mg} / \mathrm{L}, \mathrm{COD}<80 \mathrm{mg} / \mathrm{L}$, $\mathrm{SS}<30 \mathrm{mg} / \mathrm{L}$, Residual chlorine $<0.5 \mathrm{mg} / \mathrm{L}, \mathrm{FC}<1000 / 100 \mathrm{~mL}$, Helminths eggs $<1$ egg/L, B $<2 \mathrm{mg} / \mathrm{L}$, TKN $<30 \mathrm{mg} / \mathrm{L}$ according to the 141937 Common Ministerial Decision [31]. The actual concentration of pathogens in WWTP effluent, the Axios's freshwater and the mixed water are shown in Table 3. As indicated from those measurements, pathogen concentrations in the mixed water used for irrigation, were lower than those indicated by the 141937 Common Ministerial Decision (2005) as well as those by WHO [32]. In addition, concentrations of TC, E. coli, and Enterococcus spp in the wastewater effluent were significantly lower than those of the Axios' river water (Table 3).

Table 3. Concentration of pathogens in wastewater effluent, the Axios's water and mixed water.

\begin{tabular}{cccccc}
\hline \multirow{2}{*}{ Type of water } & $\begin{array}{c}\text { TC } \\
(\mathbf{M P N} / \mathbf{1 0 0} \mathbf{~ m L )}\end{array}$ & $\begin{array}{c}\text { E. coli } \\
(\mathbf{M P N} / \mathbf{1 0 0} \mathbf{~} \mathbf{L})\end{array}$ & $\begin{array}{c}\text { Enterococcus spp. } \\
(\mathbf{M P N} / \mathbf{1 0 0} \mathbf{~ m L})\end{array}$ & $\begin{array}{c}\text { Salmonella spp. } \\
(\mathbf{M P N} / \mathbf{1 0 0} \mathbf{~ m L})\end{array}$ & $\begin{array}{c}\text { Intestinal Nematodes } \\
\text { (No of eggs/L) }\end{array}$ \\
\hline WWTP effluent & $<3$ & $<3$ & $<3$ & none & none \\
Axios & 23 & 23 & $<3$ & none & none \\
Mixed & 21 & 15 & $<3$ & none & none \\
\hline
\end{tabular}


Concentrations of several chemical compounds and heavy metals in the WWTP effluent, the Axios's fresh water and the mixed water are given in Tables 4 and 5. The mixed water values of SS, $\mathrm{COD}$ and $\mathrm{BOD}_{5}$ were less than 12,18 , and $2 \mathrm{mg} / \mathrm{L}$, respectively, thus much less than those deemed satisfactory by several regulations and guidelines around the world [2,32] as well as of those considered safe by the specific regulations for this project.

Table 4. Chemical and physical parameters of the WWTP effluent, the Axios's water and mixed water (adapted from [33]).

\begin{tabular}{ccccc}
\hline Parameter & Units & Effluent & Axios & Mixed \\
\hline $\mathrm{SS}$ & $\mathrm{mg} / \mathrm{L}$ & 11 & 16 & 12 \\
$\mathrm{COD}$ & $\mathrm{mg} / \mathrm{L}$ & 60 & 16 & 18 \\
$\mathrm{BOD}_{5}$ & $\mathrm{mg} / \mathrm{L}$ & 3 & 2 & 2 \\
$\mathrm{pH}$ & & 7.27 & 7.71 & 7.6 \\
$\mathrm{EC}$ & $\mathrm{dS} / \mathrm{m}$ & 5.13 & 0.56 & 0.7 \\
$\mathrm{Ca}$ & $\mathrm{meq} / \mathrm{L}$ & 5.33 & 3.07 & 3.09 \\
$\mathrm{Mg}$ & $\mathrm{meq} / \mathrm{L}$ & 7.84 & 0.73 & 0.75 \\
$\mathrm{Na}$ & $\mathrm{meq} / \mathrm{L}$ & 49.74 & 1.35 & 1.61 \\
$\mathrm{SAR}$ & & 19.25 & 0.98 & 1.16 \\
$\mathrm{Cl}$ & $\mathrm{mg} / \mathrm{L}$ & 1250 & 50 & 75 \\
$\mathrm{~N}-\mathrm{NH}$ & $\mathrm{mg} / \mathrm{L}$ & 0.33 & 0.18 & 0.26 \\
$\mathrm{~N}-\mathrm{NO}_{3}$ & $\mathrm{mg} / \mathrm{L}$ & 9.66 & 1.1 & 1.2 \\
$\mathrm{TKN}^{-}$ & $\mathrm{mg} / \mathrm{L}$ & 10.6 & 1.4 & 1.4 \\
$\mathrm{P}^{-} \mathrm{PO}_{4}$ & $\mathrm{mg} / \mathrm{L}$ & 3.6 & $<0.5$ & 0.81 \\
$\mathrm{~K}$ & $\mathrm{meq} / \mathrm{L}$ & 0.35 & 0.06 & 0.08 \\
$\mathrm{HCO}_{3}$ & $\mathrm{meq} / \mathrm{L}$ & 5.46 & 3.32 & 3.82 \\
$\mathrm{SO}_{4}$ & $\mathrm{meq} / \mathrm{L}$ & 2.5 & 0.3 & 1.0 \\
\hline
\end{tabular}

Table 5. Concentrations of heavy metals in the WWTP effluent, the Axios's river water and mixed water in $\mathrm{mg} / \mathrm{L}$ (adapted from [33]).

\begin{tabular}{cccc}
\hline Parameter & Effluent & Axios water & Mixed water \\
\hline $\mathrm{Fe}$ & 0.27 & 0.56 & 0.36 \\
$\mathrm{Cu}$ & 0.024 & 0.03 & 0.04 \\
$\mathrm{Zn}$ & 0.215 & 0.12 & 0.15 \\
$\mathrm{Ni}$ & 0.006 & 0.62 & 0.48 \\
$\mathrm{Cd}$ & $<0.0001$ & $<0.0001$ & $<0.0001$ \\
$\mathrm{~Pb}$ & 0.002 & 0.069 & 0.061 \\
$\mathrm{Hg}$ & $<0.001$ & 0.0027 & 0.003 \\
$\mathrm{As}$ & 0.006 & 0.004 & 0.003 \\
$\mathrm{Mn}$ & 0.06 & 0.04 & 0.03 \\
$\mathrm{Cr}$ (total) & 0.001 & 0.05 & 0.02 \\
$\mathrm{~B}$ & 0.52 & 0.11 & 0.1 \\
\hline
\end{tabular}

The EC of the treated wastewater effluent was relatively high, with a value of $5.13 \mathrm{dS} / \mathrm{m}$ (Table 4). However, the EC of the irrigation water (mixed water) was within acceptable agronomical limits. In the past, several guidelines were proposed in order to protect soil and plants from irrigation water salinity 
(EC). Such guidelines were organized, modified and presented (among others) by Ayers and Westcot [34]. In order to eliminate the impacts of salinity on the productivity of agricultural land, appropriate management practices should be adopted, including the selection of suitable irrigation methods, soil cultural practices, soil drainage, and selection of salt-tolerant plant species. In the Thessaloniki case study, no detrimental impact on crops growth, production and soil was observed [24].

Two of the substances of concern in recycled water are nitrogen $(\mathrm{N})$ and phosphorus $(\mathrm{P})$. Quite often they occur in recycled water at higher concentrations than those required for optimum crop growth. Excessive application of nutrients to the land may result in the leaching of nitrates to underground aquifer and runoff of both phosphorous and nitrogen to surface waters. Nutrient transport to water bodies may degrade quality, reduce biodiversity, cause eutrophication and result in health risks if these supplies are used as potable water. Furthermore, increased concentrations of nutrients, and particularly of nitrogen, may significantly affect the yield of the irrigated crops through excessive vegetative growth at the expense of yield and lower accumulation of carbohydrates in sugar beets and fruit $[2,26]$. On the other hand, if the nutrient content of WWTP effluents is utilized with proper practices, significant quantities of fertilizers could be saved. In the Thessaloniki WWTP effluent reuse scheme, amounts of 70-125 kg N/ha and 140-320 kg P/ha (Table 4) were applied with the irrigation water in the rice fields and $17-30 \mathrm{~kg} \mathrm{~N} / \mathrm{ha}$ and $35-80 \mathrm{~kg} \mathrm{P} / \mathrm{ha}$ to other crops. Further work is required to investigate the potential effects of nutrient content of the treated effluent to crops, groundwater and the environment.

Finally, other nutrients and heavy metals were within the limits reported by Ayers and Westcot [34], Panoras and Ilias [35], Paranychianakis et al. [2], and others.

Additional measures in the Thessaloniki reuse project include the restriction of effluent application to crops that are consumed raw by humans while, in the case of horticultural crops, irrigation must cease at least two weeks before harvesting. Farmers are encouraged to use trickle irrigation to minimize the contact of crop and humans with recycled water, while the use of sprinklers is prohibited. Moreover, notices should be placed in the effluent-irrigated fields and effluent (mixed water) conveying canals. Educational programs are to be implemented to inform farmers of the safe use of the recycled water, to promote public acceptance and familiarize farmers and public with the idea of treated wastewater reuse in crop irrigation.

\section{Current Quality Criteria}

A preliminary study about WWTP effluent quality criteria was implemented in 2000 by the Hellenic Union of Water Supply and Sewerage Services Association and was mainly influenced by the WHO guidelines [36]. This study was updated in 2009 taking into account the scientific standards of that time and suggested criteria based on the revised WHO and Australian guidelines [10], but these criteria were not adopted by Greek authorities. In March 2011, the 145116 Common Ministerial Decision [37] was published and set effluent reuse criteria that were applicable to any project using recycled water in Greece. These criteria define treatment processes, water quality limits and, in some applications, additional measures to protect consumers, workers and, in general, public health and the environment (Tables 6 and 7). 
Table 6. Microbiological and chemical parameter limits, minimum required treatment and frequency of sampling in the case of reuse of treated effluent for irrigation, industrial use, and aquifer recharge.

\begin{tabular}{|c|c|c|c|c|c|c|}
\hline Category of use & $\begin{array}{c}\text { E. coli } \\
(\mathrm{cfu} / 100 \mathrm{~mL})\end{array}$ & $\begin{array}{l}\mathrm{BOD}_{5} \\
(\mathrm{mg} / \mathrm{L}) \\
\end{array}$ & $\begin{array}{r}\text { TSS } \\
(\mathrm{mg} / \mathrm{L}) \\
\end{array}$ & $\begin{array}{c}\text { Turbidity } \\
\text { (NTU) }\end{array}$ & $\begin{array}{l}\text { Required } \\
\text { treatment }\end{array}$ & $\begin{array}{l}\text { Sampling } \\
\text { frequency }\end{array}$ \\
\hline $\begin{array}{l}\text { Restricted irrigation } \\
\text { Areas where public access is not expected, } \\
\text { fodder and industrial crops, pastures, trees } \\
\text { (except fruit trees), provided that at the } \\
\text { harvest fruits are not in contact with the soil, } \\
\text { seed crops and crops whose products are } \\
\text { further processed before consumption. } \\
\text { Sprinkler irrigation is not allowed } \\
\text { Industrial use } \\
\text { Disposable cooling water } \\
\text { Groundwater recharge } \\
\text { Aquifer recharge that doesn't fall in the cases } \\
\text { described by Article } 751 / 2-3-2007 \text { of Decree } \\
\text { (with care to par. } 4 \text { and } 5 \text { of Article 5) by } \\
\text { percolation through soil layer with sufficient } \\
\text { thickness and appropriate properties }{ }^{\mathrm{d}}\end{array}$ & $\leq 200$ median & $\begin{array}{l}\text { According } \\
\text { to CMD } \\
5673 / 400 / \\
1997\end{array}$ & $\begin{array}{l}\text { According } \\
\text { to CMD } \\
5673 / 400 / \\
1997\end{array}$ & & $\begin{array}{l}\text { Secondary } \\
\text { biological } \\
\text { treatment }^{\mathrm{a}, \mathrm{b}} \text { and } \\
\text { disinfection }^{\mathrm{c}}\end{array}$ & $\begin{array}{l}\mathrm{BOD}_{5}, \mathrm{TSS}, \mathrm{N}, \mathrm{P}: \\
\text { under the } \\
\text { requirements of } \\
\mathrm{CMD} 5673 / 400 / 97 \\
\text { (GJ 192/B/14.3.97). } \\
\mathrm{EC}: \text { one/week. } \\
\mathrm{Cl}_{2} \text { : continuous } \\
\text { (If chlorination } \\
\text { is applied) }\end{array}$ \\
\hline $\begin{array}{l}\text { Unrestricted irrigation } \\
\text { All crops such as fruit trees, vines, } \\
\text { vegetables, or crops whose products eaten } \\
\text { raw, greenhouses. } \\
\text { All irrigation methods, including sprinklers, } \\
\text { can be applied. } \\
\text { Industrial use, except disposable } \\
\text { cooling water } \\
\text { Circulating cooling water, water for boilers, } \\
\text { various processes, etc. }\end{array}$ & $\begin{array}{l}\leq 5 \text { for } 80 \% \text { of } \\
\text { samples and } \\
\leq 50 \text { for } 95 \% \\
\text { of samples }\end{array}$ & $\begin{array}{l}\leq 10 \text { for } \\
80 \% \text { of } \\
\text { samples }\end{array}$ & $\begin{array}{l}\leq 10 \text { for } \\
80 \% \text { of } \\
\text { samples }\end{array}$ & $\leq 2$ median & $\begin{array}{l}\text { Secondary } \\
\text { biological } \\
\text { treatment }^{\mathrm{e}} \\
\text { followed or } \\
\text { higher treatment }^{\mathrm{f}} \\
\text { and disinfection }^{\mathrm{g}}\end{array}$ & $\begin{array}{l}\mathrm{BOD}_{5}, \mathrm{TSS}, \mathrm{N}, \mathrm{P}: \\
\text { according to CMD } \\
\text { requirements } \\
\text { Turbidity and } \\
\text { permeability of } \\
\text { effluent } 4 / \text { week for } \\
\text { WWTPs }>50,000 \\
\mathrm{PE} \text { and } 2 / \text { week in } \\
\text { any other case. } \\
\text { EC: } 4 / \text { week for } \\
\text { WWTPs with } \\
>50,000 \text { PE and } \\
2 / \text { week in any } \\
\text { other case. } \\
\mathrm{Cl}_{2} \text { : continuous }\end{array}$ \\
\hline
\end{tabular}

a,b,c,d,e,f,g,h Further information and details in Common Ministerial Decision No. 145116, 2011.

Current Greek regulations [37] distinguish the following applications: (a) urban uses including landscape irrigation, recreational uses, car washing, and fire protection, (b) irrigation of agricultural crops and commercial nurseries with or without restrictions, (c) industrial uses such as cooling, boiler feeding, processes that require water use, etc., and (d) recharge of aquifers not used for potable water uptake. The regulations distinguish three basic effluent qualities with respect to microbiological criteria [2]:

(a) The highest quality which refers to urban uses and direct injection for groundwater recharge, with a threshold of $2 \mathrm{cfu} / 100 \mathrm{~mL}$ for TC (Table 7). 
(b) The medium quality refers to unrestricted irrigation and to industrial uses except that of disposable cooling water, with a threshold of $5 \mathrm{cfu} / 100 \mathrm{~mL}$ for $E$. coli (Table 6).

(c) The lowest effluent quality refers to restricted irrigation, aquifer recharge by percolation and to disposable industrial use (cooling), with a threshold for E. coli of $200 \mathrm{cfu} / 100 \mathrm{~mL}$ (Table 6).

Table 7. Microbiological and chemical parameter limits, minimum required treatment, frequency of sampling for effluent reuse in urban and suburban uses and aquifer recharge.

\begin{tabular}{|c|c|c|c|c|c|c|}
\hline Category of use & $\begin{array}{c}\text { TC } \\
(\mathrm{cfu} / \mathbf{1 0 0} \mathbf{~ m L})\end{array}$ & $\begin{array}{c}\text { BOD }_{5} \\
(\mathrm{mg} / \mathrm{L})\end{array}$ & $\begin{array}{c}\text { TSS } \\
(\mathrm{mg} / \mathrm{L})\end{array}$ & $\begin{array}{c}\text { Turbidity } \\
\text { (NTU) }\end{array}$ & $\begin{array}{l}\text { Required } \\
\text { treatment }\end{array}$ & Sampling frequency \\
\hline $\begin{array}{l}\text { Urban uses: } \\
\text { Large areas of urban use } \\
\text { (cemeteries, golf courses, public } \\
\text { parks, freeway embankments), } \\
\text { recreational facilities, fire } \\
\text { protection, soil compaction, street } \\
\text { cleaning and decorative fountains. } \\
\text { Sprinkler irrigation is } \\
\text { not allowed } \\
\text { Recharge aquifers by wells } \\
\text { not fall under Article } 7 \text { of } \\
\text { Decree 51/2-3-2007 } \\
\text { (GJ54A/8-3-2007). } \\
\text { Peri-urban green }{ }^{\text {d }} \\
\text { including groves and forests }\end{array}$ & $\begin{array}{l}\leq 2 \text { in } 80 \% \\
\text { of samples } \\
\text { and } \leq 20 \text { in } \\
95 \% \text { of } \\
\text { samples }\end{array}$ & $\begin{array}{l}\leq 10 \text { in } \\
80 \% \text { of } \\
\text { samples }\end{array}$ & $\begin{array}{l}\leq 2 \text { in } \\
80 \% \text { of } \\
\text { samples }\end{array}$ & $\leq 2$ median & $\begin{array}{l}\text { Secondary } \\
\text { biological } \\
\text { treatment }^{\mathrm{a}} \\
\text { followed by } \\
\text { advanced } \\
\text { treatment }^{\mathrm{b}} \text { and } \\
\text { disinfection }^{\mathrm{c}}\end{array}$ & $\begin{array}{l}\mathrm{BOD}_{5} \text {, TSS, N, P: } \\
\text { according to the CMD } \\
\text { Turbidity and } \\
\text { permeability of effluent } \\
\text { 4/week for WWTPs > } \\
50,000 \text { PE and } 2 / \text { week } \\
\text { in any other case. } \\
\mathrm{Cl}_{2} \text { : continuously (If } \\
\text { chlorination is applied) }\end{array}$ \\
\hline
\end{tabular}

a,b,c,d Further information and details in Common Ministerial Decision No. 145116, 2011.

Additionally to the effluents' quality limits and treatment processes described in Tables 6 and 7, the latest Greek regulations include maximum concentrations for 19 heavy metals and metalloids, as well as numerous barriers for each application, which are expected to discourage the development of water recycling projects. For example, monitoring of heavy metals and metalloids is required and varies with the capacity of the WWTP from $2(<10,000$ EP) to $12(200,000$ EP and bigger $)$ times per year. In addition, a set of 40 organic substances should be monitored two times per year in WWTPs serving more than 100,000 EP [2].

Furthermore, in order to use the effluent for irrigation, the regulations define agronomical thresholds for various parameters based on the Ayers and Westcot [34] guidelines and maximum allowable concentrations of priority substances and toxicity in the reused water.

\section{Conclusions}

In Greece, because of the restricted water resources and of the high demand for freshwater with a peak during the hot period, it is essential that every possible water resource is exploited. Crop irrigation is one of the most demanding water consumers, especially during summer. At the eastern and southern regions of the country, the integration of treated wastewater into water resources management is of paramount importance to meet current and future demands. Despite this need, only a few projects of effluent reuse have been implemented, and most of them are pilot projects dealing with crop or 
landscape irrigation. The most important projects which are currently in practice include those of Thessaloniki, Chalkida, Malia, Livadia, Amfisa, Kalikratia, and Chersonissos. One of the most significant wastewater reuse projects is that of Thessaloniki, in northern Greece. In this project, the treated wastewater is mixed with freshwater at a ratio of 1:5, mostly because of the high salinity of the effluent. A fraction of the total WWTP discharge of $165,000 \mathrm{~m}^{3} /$ day is mixed with the Axios's river water to irrigate approximately 2500 ha of rice, corn, alfalfa, sugar beet, and cotton.

A few other projects are under planning, such as that in Iraklion, in Agios Nikolaos, and on several Aegean islands. It should be mentioned that there are several cases of indirect reuse of WWTPs effluent in central Greece. However the reuse potential in Greece is limited, since effluent recycling from Athens's WWTP, which serves approximately half of the Greek population, is not economically feasible due to the location of the treatment plant.

The increasing pressure on water resources in Greece-especially in southern and eastern Greece - can only be met by the adoption of integrated water management schemes. Emphasis should be given to the efficient use of existing water supplies, to the protection of their quality, as well as to the use of marginal waters, such as treated effluents. A saving of $4.5 \%$ to $5 \%$ of the total water use could be achieved by proper management and reuse of the effluents from the existing WWTPs. This percentage may increase in the near future as the number and the capacity of WWTPs increases and as new plants will be incorporated in effluent reuse schemes. In order to achieve this, national water policy should be improved and extended to encourage the safe use of recycled water for various uses.

Recently, quality criteria for treated wastewater reuse have been established in Greece, for various reuse options. Projects that have already been implemented are required to conform to the new regulations [37].

\section{Acknowledgments}

Part of this work was presented in the IWA Regional Conference on Wastewater Purification \& Reuse. Iraklion, Hellas, 28-30 March 2012.

\section{Author Contributions}

Andreas Ilias coordinated the preparation of the manuscript, collected and organized the data, and was the corresponding author, Athanasios Panoras analyzed and codified the data, and contributed to manuscript preparation and Andreas Angelakis had the original idea, supervised the research and review it.

\section{Conflicts of Interest}

The authors declare no conflict of interest.

\section{References}

1. Asano, T.; Burton, F.L.; Leverenz, H.L.; Tsuchinhashi, R.; Tchobanoglous, G. Water Reuse: Issues, Technologies, and Applications; McGraw-Hill: New York, NY, USA, 2007. 
2. Paranychianakis, N.V.; Salgot, M.; Angelakis, A.N. Irrigation with recycled water: Guidelines and regulations. In Treated Wastewater in Agriculture: Use and Impacts on the Soil Environments and Crops; Levy, G., Fine, A., Bar-Tal, A., Eds.; Wiley Knowledge for Generations: Hoboken, NJ, USA; Oxford, UK, 2011; Chapter 3, pp. 77-111.

3. Marecos do Monte, M.H.F.; Angelakis, A.N.; Asano, T. Necessity and basis for the establishment of European guidelines on wastewater reclamation and reuse in the Mediterranean region. Water Sci. Technol. 1996, 33, 303-316.

4. Angelakis, A.N.; Marecos do Monte, M.H.; Bontoux, L.; Asano, T. The status of wastewater reuse practice in the Mediterranean Basin. Water Res. 1999, 33, 2201-2217.

5. Angelakis, A.N.; Diamadopoulos, E. Water resources management in Greece: Current status and prospective outlook. Water Sci. Technol. 1995, 32, 267-272.

6. Kalavrouziotis, I.K.; Kokkinos, P.; Oron, G.; Fatone, F.; Bolzonella, D.; Vatyliotou, M.; Fatta-Kassinos, D.; Koukoulakis, P.H.; Varnavas, S.P. Current Status in Wastewater Treatment, Reuse and Research in Some Mediterranean Countries. Desalin. Water Treat. 2013, doi:10.1080/ 19443994.2013.860632.

7. Chartzoulakis, K.S.; Paranychianakis, N.V.; Angelakis, A.N. Water resources management in the island of Crete, Greece: With emphasis the agricultural use. Water Policy 2001, 3, 193-205.

8. Panoras, A.; Ilias, A. Reclaimed municipal wastewater reuse in Thessaloniki. In Proceedings of the International Symposium on Wastewater Reclamation and Reuse, Thessalonki, Greece, 13-14 February 2003; pp. 137-145.

9. Tsagarakis, K.P.; Dialynas, G.E.; Angelakis, A.N. Water resources management in Crete (Greece) including water recycling and reuse and proposed quality criteria. Agric. Water Manag. 2004, 66, $35-47$.

10. Paranychianakis, N.V.; Kotselidou, O.; Vardakou, E.; Angelakis, A.N. Greek Regulations on Wastewater Reclamation and Reuse; Hellenic Union of Municipal Enterprises for Water Supply and Sewage: Larissa, Greece, 2009; pp. xxiv, 160. (In Greek)

11. EU. Council Directive 91/271/EEC concerning urban waste water treatment. Offic. J. EU: Legislation 1991, 56, 40-52.

12. MEECC (Ministry of Environment, Energy and Climate Change). Greek State Conformation to the EU 271/91 Directive; MEECC: Athens, Greece, 2010.

13. Tsagarakis, K.P.; Mara, D.D.; Angelakis, A.N. Evaluation of municipal wastewater treatment plants in Greece. Tech. Chron. 1998, 18, 97-109. (In Greek)

14. Mamais, D.; Andreadakis, A.D.; Gavalaki, E. Assessment of secondary and tertiary treatment processes for wastewater reclamation in Greece. In Proceedings of the IWA Regional Symposium on Water Recycling and Reuse, Iraklion, Greece, 26-29 September 2002.

15. Andreadakis, A.; Mamais, D.; Gavalakis, E.; Panagiotopoulou, V. Evaluation of treatment schemes appropriate for wastewater reuse in Greece. Glob. Nest: Int. J. 2004, 5, 1-8.

16. Panoras, G. Heavy Metal Accumulation in Soil Irrigated for Six Years by Treated Municipal Wastewater. Master's Thesis, Aristotle University of Thessaloniki, Thessaloniki, Greece, 2011. (In Greek)

17. Angelakis, A.N.; Koutsoyiannis, D.; Tchobanoglous, G. Water resources technologies in the ancient Greece. Water Res. 2005, 39, 210-216. 
18. Koutsoyiannis, D.; Zarkadoulas, N.; Angelakis, A.N.; Tchobanoglous, G. Urban water management in ancient Greece: Legacies and lessons. ASCE J. Water Resour. Plan. Manag. 2008, 134, 45-54.

19. Tzanakakis, V.E.; Koo-Oshima, S.; Haddad, M.; Apostolidis, N.; Angelakis, A.N. The history of land application and hydroponic systems for wastewater treatment and reuse. In Evolution of Sanitation and Wastewater Management through the Centuries; Angelakis, A.N., Wilderer, P.A., Rose, J.B., Eds.; IWA Publishing: London, UK, 2014, accepted.

20. Tsagarakis, K.P.; Tsoumanis, P.; Chartzoulakis, K.; Angelakis, A.N. Water resources status including wastewater treatment and reuse in Greece: Related problems and prospectives. Water Int. 2001, 26, 252-258.

21. Sbirilis, N.; Kanaris, S. Wastewater reclamation and reuse in city of Chalkis, Greece. In Proceedings of the IWA Regional Symposium on Water Recycling in Mediterranean Region, Iraklion, Greece, 26-29 September 2002; pp. 63-68.

22. EYDAP (Athens Water Supply and Sewage Company). Personal communication, 2013.

23. Soupilas, A.; Papastergiou, F. Preparations for large scale reuse of treated domestic wastewater for irrigation purposes in Thesaloniki. In Proceedings of the IWA Regional Symposium on Water Recycling in Mediterranean Region, Iraklion, Greece, 26-29 September 2002; pp. 465-471.

24. Ilias, A.; Panoras, G.; Karamoutzis, D.; Angelakis, A.N. Reuse of treated wastewater in Greece: The project of Thessaloniki. In Proceedings of the IWA Regional Conference on Wastewater Purification \& Reuse, Iraklion, Greece, 28-30 March 2012; p. 183.

25. Papayiannopoulou, A.; Parissopoulos, G.; Panoras, A.; Kampeli, S.; Papadopoulos, F.; Papadopoulos, A.; Ilias, A. Emitter performance in conditions of treated municipal wastewater. In Proceedings of the 2nd International Conference Entitled "Advanced Wastewater Treatment, Recycling and Reuse. AWT98", Fiera, Milano, Italy, 14-16 September 1998; pp. 1011-1014.

26. Panoras, A.; Ilias, A.; Skarakis, G.; Zdragas, A. Suitability of reclaimed municipal wastewater for sugar beet irrigation. In Proceedings of the 5th International Congress on Environmental Pollution, Thessaloniki, Greece, 28 August-1 September 2000; pp. 221-232.

27. Panoras, A.; Kehagia, U.; Xanthopoulos, F.; Doitsinis, A.; Samaras, I. The use of municipal wastewater in cotton irrigation. In Proceedings of the Inter-Regional Research Network Meeting on Cotton, Chania, Greece, 27-30 September 2001.

28. Panoras, A.; Evgenidis, G.; Bladenopoulou, S.; Melidis, B.; Doitsinis, A.; Samaras, I.; Sdragkas, A.; Matsi, T. Corn irrigation with reclaimed municipal wastewater. Glob. Nest: Int. J. 2005, 5, 47-54.

29. Papadopoulos, F.; Parissopoulos, G.; Papadopoulos, A.; Zdragas, A.; Ntanos, D.; Prochaska, C.; Metaxa, I. Assessment of reclaimed municipal wastewater application on rice cultivation. Environ. Manag. 2009, 43, 135-143.

30. Panoras, A.; Ilias, A.; Hatzigiannakis, E.; Arampatzis, G.; Panagopoulos, A.; Stathaki, S.; Diamantidis, I.; Tsekoura, D.; Zavra, A.; Panoras, G.; et al. Final Report of Reusing the Reclaimed Municipal Effluent of Thessaloniki's Wastewater Treatment Plant for Irrigation Purposes in Halastra-Kalohori Agricultural Area During the Summer Time of 2008; NAGREF: Sindos, Greece, 2009; p. 54. (In Greek)

31. CMD (Common Ministerial Decision). Criteria for Reusing the Effluent from Thessaloniki's WWTP in Sindos; No. 141937; Ministry of Environment, Energy and Climate Change: Athens, Greece, 2005. (In Greek) 
32. WHO (World Health Organization). Guidelines for the Safe Use of Wastewater, Excreta, and Greywater; Wastewater Use in Agriculture; WHO: Geneva, Switzerland, 2006; Volume 2.

33. Soupilas, A. Technical Report on Treated Wastewater Reuse in Thessaloniki, Greece; EYATH, A.E.: Thessaloniki, Greece, 2011. (In Greek)

34. Ayers, R.S.; Westcot, D.W. Water Quality for Agriculture; FAO Irrigation and Drainage. Paper 29, Rev. 1; Food and Agriculture Organization of the United Nations: Rome, Italy, 1985.

35. Panoras, A.; Ilias, A. Irrigation with Treated Wastewater Effluent; Giahudis: Thessaloniki, Greece, 1999; p. 190. (In Greek)

36. Angelakis, A.N.; Tsagarakis, K.P.; Kotselidou, O.N.; Vardakou, E. The Necessity for Establishment of Greek Regulations on Wastewater Reclamation and Reuse; Report for the Ministry of Public Works and Environment and Hellenic Union of Municipality Entering for Water Supply and Sewage: Larissa, Greece, 2000; p. 110. (In Greek)

37. CMD (Common Ministerial Decision). Measures, Limits and Procedures for Reuse of Treated Wastewater; No. 145116; Ministry of Environment, Energy and Climate Change: Athens, Greece, 2011. (In Greek)

(C) 2014 by the authors; licensee MDPI, Basel, Switzerland. This article is an open access article distributed under the terms and conditions of the Creative Commons Attribution license (http://creativecommons.org/licenses/by/3.0/). 